\title{
Philosophy Journals as Current Book Selection Guides
}

\begin{abstract}
In an effort to determine the adequacy of book review coverage in the fields of philosophy, thirteen philosophy journals were studied for a period of one year, and the books reviewed in them tabulated. These reviews were also correlated with library review media and compared with reviews during the same period in the Library Journal and Choice. Results indicate that comprehensive coverage is available only in the philosophy journals.
\end{abstract}

"J UST NAMING SOME of the topics covered by the Dewey classification in the field of philosophy suggests a major problem: ontology, cosmology, epistemology, teleology, positivism, nominalism ... philosophy is a very technical subject, indeed."1 In so saying, Carter and Bonk, in their book, Building Library Collections, have put their fingers on the crux of the selection problem in the field of philosophy.

The college or university librarian who is expected to take full responsibility for the completeness of a collection in philosophy, without help from the departmental specialists in the field, has a problem indeed. Not only are the areas within the field many and diverse, but also the terminology itself demands intimate knowledge of this complex discipline. Common sense is not enough here, in a field where even terminologies such as "realism" and "idealism" have meanings totally different from ordinary usage.

The current tools discussed in this paper are those which the librarian might regularly use to fill out the collection. Even if a good relationship were

${ }^{1}$ Mary Duncan Carter and Wallace John Bonk, Building Library Collections (New York: Scarecrow Press, 1959), p. 96.

Miss Copeland is Catalog Librarian, Drew University, Madison, New Jersey. assumed between department and library, a broad interest on the part of the department cannot necessarily be assumed, because, although one might hope that this would be the case, departments do change, and the subject specialty of its present members must not unbalance the collection as a whole. In other words, if a department becomes heavy with men interested in the philosophy of science, the librarian's job becomes that of making sure that the collection includes works in aesthetics and philosophy of religion. The librarian can never abdicate responsibility for a collection in a subject field, however esoteric and technical that field might be; he must keep abreast of the subject matter as best he can and keep the general collection in order.

It is with this purpose in mind that the current reviewing tools available in the field of philosophy were analyzed; first in terms of the journals themselves, and secondly in terms of a study of the books reviewed in them. Many of these journals cover foreign books, some even having reviews written in foreign languages; the journals are published all over the world. Some of the reviews, however, lend themselves more to philosophical debate than to use as a library tool.

In all cases, of course, the reviewing tool is only as good as the specific re- 
viewer. Reviews vary from person to person and from topic to topic; generalization is almost impossible. The Journal of Philosophy, for example, publishes only first-rate philosophical papers, but in the review columns one has to decide whether a particular philosopher is writing a first-rate review or whether he is grinding his own philosophical ax.

Another problem in using professional journals for current book selection is that often books are reviewed in them long after the book is actually published. Not all are guilty of an undue time lag and in the long run, a book that is worth having and which had not been ordered upon publication is worth having later.

Because of this time lag, and because of the difficulty in reading all of the journals in all areas for which a librarian finds himself responsible, would the librarian be justified in relying solely on library reviewing tools to fill out the collection in philosophy? In order to answer this question a comparison was made of the coverage of books reviewed in philosophy journals with those reviewed in two widely used library tools, Library Journal and Choice. Also noted are the journals which are covered by Book Review Digest (BRD), Book Review Index (BRI), and the Index to Book Reviews in the Humanities (IBRH). It is interesting to note the comment by Frances J. Kirschenbaum that of all the subjects indexed in the Index to Book Reviews in the Humanities. "Only the field of philosophy is at present well covered." 2 The books referred to as reviewed in the philosophy journals were reviewed in 1964 only, thus giving a survey of one complete year's coverage.

\section{Notes on Reviewing in the PhiLosophy Journals}

Journal of Aesthetics and Art Criticism. Published quarterly (two issues only in 1964) by the American Society

\footnotetext{
${ }^{2}$ Frances J. Kirschenbaum, "Periodicals in the $\mathrm{Hu}-$ manities," Library Trends, X (January 1962), 326.
}

for Aesthetics at Wayne State University, the College of Liberal Arts, the University Press, and the Cleveland Museum of Art. The American Society for Aesthetics was "organized in 1942 for the advancement of philosophical and scientific studies of the arts and related fields." This journal is included in society membership.

The 1964 fall issue was completely devoted to articles in honor of the former editor of the journal and had no book reviews. The winter issue included long signed reviews with the name of the college of the reviewer. It included reviewers from the Cleveland Museum of Art.

About fifteen books are reviewed in an issue, only one of which in the winter issue was strictly a philosophy book; the others were in art and literature. It may be that this journal would not be valuable in the field of philosophy, depending upon the arrangement of courses in aesthetics in the particular school.

Journal of Symbolic Logic. Published quarterly by the Association for Symbolic Logic, Inc., with support from UNESCO through ICSO and from institutional members. It comes out three times a year, in March, June, and September.

It reviews both books and journal articles. The reviews are in English, but they include articles from foreign language periodicals. Each issue contains reviews of four or five books which are scattered among reviews of articles. Current bibliographies of individual authors are compiled, e.g. Ernest Nagel had a listing of nine books and articles.

The September issue was devoted to abstracts of papers given at the annual meeting of the Association and had no reviews. This is a technical field and has technical reviews. Cross references from journal articles abound.

Journal of the History of Philosophy. Published twice a year by the University of California Press. "The Journal of the 
History of Philosophy is an international journal which publishes articles, notes, discussions, and reviews about the history of western philosophy, broadly conceived. . . . Publishes material in English, French and German." And hopes for Spanish and Italian in the future.

This journal has long signed reviews, occasionally in French. It is apt to have long quotations from the book in the original language even though the review may be in English.

The section called Book Notes has capsule annotations for about four books per issue. "New Translations" lists and annotates about six. "New Editions" has about nine. It also contains a section called "Books Received" which lists many more but without comment.

Journal of Philosophy (BRD, BRI, IBRH). This is one of the leading journals in the field, published fortnightly at Columbia by the Journal of Philosophy, Inc. (every four weeks in July and August). The October and November issues contained agenda and papers for the American Philosophical Association meetings. Some issues have no reviews; others have one or two. All are long, signed philosophical reviews. Occasional sections list "New Books" with the length varying from nine to fifty of the unannotated lists. February 27 issue listed "Paperbacks, Reprints, and Anthologies"-four of them; October 29 cited "Reprints and Selected Writings."

Mind (IBRH). "A Quarterly Review of Psychology and Philosophy" edited by Gilbert Ryle at Oxford. Published quarterly, January, April, July, and October.

"New Books" contains long signed reviews, almost exclusively in philosophy. It includes foreign language books, although they are reviewed in English.

"Received Also" section is one which lists about sixty-six books, a larger percentage of which are in psychology than are the reviews, and which also includes foreign language books.

Philosophical Books. Issued three times a year, January, May, October, by the Leicester University Press.

This is the only journal devoted exclusively to book reviews. It averages about twenty-three an issue. Shorter articles tend to be more to the point of the book-are less apt to be philosophical dissertations.

The journal lists collections separately, although without review, at the end. It tends to be up-to-date, even the January 1964 issue had only 1963 books. The October issue reviewed only 1964 books.

The Philosophical Review (IBRH) (BRI contemplated). Quarterly journal, edited by the Sage School of Philosophy, Cornell University. Published January, April, July, and October.

This is a first-class journal with high reviewing standards. Articles are signed and university origin is given-some of the outstanding names in American and British philosophy appear in these pages. Mostly American books are reviewed, with a sprinkling of British and French imprints in the year 1964. Most of the books which were reviewed in 1964 were published in 1962.

The section entitled "Books Received" gives current listing of some one hundred books per issue.

For the most part these are long critical articles, often consisting of philosophical critiques on the part of the reviewer. The use of regular size print in the Book Review section makes it easier to use.

The Philosophical Quarterly (IBRH). Published by the University of St. Andrews for the Scots Philosophical Club. Four times a year: January, April, July, and October.

The January issue was devoted to books on Greek philosophy, both articles and book reviews. Other issues covered all areas and many countries, including foreign language books.

Most of the books included in the 1964 issues were published in 1962, a few in 1963. It has a "Books Received" section 
with some one hundred current books. The reviews are long, critical, and signed.

Philosophy (IBRH). The Journal of the Royal Institutes of Philosophy. Published quarterly by Macmillan (Journals) Ltd., London.

Fewer books were reviewed than has been the case in other journals (about three to five an issue) but all were 1963 imprints in the year 1964. "Books Received" varies from thirteen to eightyfour. These are signed articles, mostly British and American books, some others. Prices are given in British currency even if the books are published in America.

Philosophy and Phenomenological Research (IBRH). "A Quarterly Journal" but 1964 had only two isssues: September and December-a symptom of the times as regards journals. Published for the International Phenomenological Society by the University of Buffalo Foundation, Inc.

This tends to be more up-to-date than some of the other journals-almost all of the books reviewed in 1964 were published in 1963. The reviews consist of short, signed articles. They are perhaps less apt to be philosophical exegeses than book reviews. It contains between twenty-three and twenty-five an issue.

All books reviewed were American except for two French books in the second issue.

Philosophy East and West. A quarterly journal of Oriental and comparative thought. Published by the University of Hawaii Press. "Articles in the field of Oriental and East-West comparative philosophy from all parts of the world." Articles are in English; editors have offered to translate if the original author cannot.

"Books reviewed are limited to those in the field of Oriental and comparative philosophy." It contains about four or five per issue. "Books Received" are not so limited, but most of them do pertain to these fields. It lists about forty books an issue.
The books reviewed in 1964 were from 1960-1963. They included authors and publishers from all over the world, with a heavy emphasis on the Far East.

A section called "Current Periodicals" lists articles in various journals within the field of Oriental and comparative philosophy. Occasionally a full table of contents is published. Titles in Chinese and Japanese are transliterated. It has a helpful bibliography of foreign journals, although only the city is given and not the name of the publisher. Journals are included from Calcutta, Bologna, Madras, Tokyo, etc.

The October issue had a "News and Notes" section which gave a bibliography of Chinese philosophy in Germany since 1950. It did not include Germans working in America.

This would be very helpful in a college or university with many foreign students, or with a particularly strong department of eastern philosophy.

Philosophy of Science (IBRH) (BRD) (BRI contemplated). Official Journal of the Philosophy of Science Association. Published quarterly by the St. Catherine Press, Bruges, Belgium, although an American publication-it is sponsored by the Institute for the Unity of Science and by Section $\mathrm{L}$ of the AAAS, with Richard Rudner of Washington University, St. Louis, as the editor.

The January issue had no book reviews, but contained short abstracts from Inquiry, and the British Journal for Philosophy of Science, 1962-63, which included two "Review Discussions" and two recommended books on the subject. The April issue had seven book reviews; none in July. The October issue had not been received at the time of this study.

Review of Metaphysics (IBRH). "The Review of Metaphysics is devoted to the promotion of technically competent definitive contributions to philosophical knowledge. It is not associated with any school or group, not the organ of any association or institution; it is interested in persistent, resolute inquiries into root 
questions, regardless of the writer's affiliations." A list of sustaining institutions, some thirty of them, is given on the back.

A somewhat different approach is given to the reviewing section. It consists of summaries and comments, a brief résumé, report or criticism written not by outside reviewers but by members of the staff, with some outside help. They are short concise comments, much more like annotations than reviews. They review mostly books in 1963 or 1964 because of this, and are therefore more upto-date. Each volume reviews some forty to eighty books.

There is a section on doctoral dissertations, 1964, listing by university the name, title, and advisor of each in the field of philosophy.

A section called "Critical Studies" gives long essays on previously published books and philosophers. Metaphysics is a fairly broad term and a few books included are by Sartre, Bonhoeffer, T. S. Eliot and C. S. Lewis, whom we tend to think of primarily in connection with other fields.

\section{Comparative Analysis}

The philosophy journals published in 1964 contained reviews of 493 books. Of these, 336 were listed in one journal only, leaving 157 which were duplicate entries. Some were listed in two journals, others in three or four, but none in more than four. Two of these journals, Aesthetics and Philosophy East and West, had no books at all that were listed in our journals of philosophy, although two of the twenty-one books in Philosophy East and West were listed in Library Journal.

A breakdown of the division of the listings is given in Table 1 . As can be seen, Philosophical Books is the only one that has a large percentage covered in other journals, thirty-six as compared to twenty-seven which are covered only in it. It must be remembered, however, that this is strictly a reviewing journal, with short annotations which are in general very helpful. To disregard it because the majority of books are covered in other journals would be both to discard a useful tool as well as to neglect the twentyseven books that are not covered elsewhere.

A second point to consider is how many of these journals are covered in the regularly used library reviewing tools. Since philosophy journals are so technical in their presentation for the most part, would it not be helpful to find reviews in, for instance, Library Journal? Another gain would supposedly be the fact that $L J$ and other general tools come out more promptly with their

TABLE 1. Comparison of Books Reviewed in Philosophy Journals, 1964

\begin{tabular}{|c|c|c|c|c|c|}
\hline Journal & $\begin{array}{c}\text { Single } \\
\text { Journal }\end{array}$ & $\begin{array}{c}\text { Two } \\
\text { Journals }\end{array}$ & $\begin{array}{c}\text { Three } \\
\text { Journals }\end{array}$ & $\begin{array}{c}\text { Four } \\
\text { Journals }\end{array}$ & Total \\
\hline $\begin{array}{l}\text { Aesthetics } \\
\text { History of Philosophy } \\
\text { Journal of Philosophy } \\
\text { Mind } \\
\text { Philosophical Books } \\
\text { Philosophical Review } \\
\text { Philosophical Quarterly } \\
\text { Philosophy } \\
\text { Phil. and Phen. Research } \\
\text { Phil. East and West } \\
\text { Phil. of Science } \\
\text { Review of Metaphysics } \\
\text { Symbolic Logic }\end{array}$ & $\begin{array}{r}15 \\
41 \\
19 \\
17 \\
27 \\
21 \\
30 \\
8 \\
24 \\
21 \\
5 \\
99 \\
9\end{array}$ & $\begin{array}{r}2 \\
8 \\
7 \\
26 \\
8 \\
12 \\
4 \\
11 \\
2 \\
20 \\
5\end{array}$ & $\begin{array}{r}2 \\
2 \\
3 \\
8 \\
6 \\
6 \\
5 \\
3 \\
8 \\
\cdots \quad 1 \\
1 \\
4\end{array}$ & 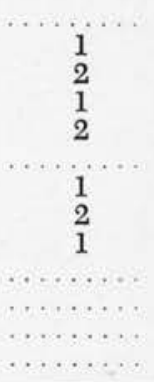 & $\begin{array}{r}15 \\
46 \\
31 \\
28 \\
63 \\
35 \\
48 \\
17 \\
44 \\
21 \\
8 \\
123 \\
14\end{array}$ \\
\hline Totals . & 336 & 105 & 42 & 10 & 493 \\
\hline
\end{tabular}


book reviews, and one could avoid the time lag of the philosophy journals. To check on this possibility the philosophy sections of $L J$ were studied for both 1964 and 1963, in case the earlier reviewing had picked up more books. Of the total of 493 philosophy books, only a total of nineteen books were covered in both years of Library Journal-thirteen in 1963 and six in 1964. Clearly Library Journal offers no adequate substitute for the reviewing of the philosophy journals.

As a secondary check the available issues of Choice were also consulted; it began publication in March 1964. In spite of the limited number of issues published, a slightly higher number were found here than in $L J$-a total of sixteen books covered, nine of these in Review of Metaphysics, two in Philosophical Books, and five from both of these. This hardly seems generous, however, when compared with the total of 123 books in the Review of Metaphysics alone.

Only two books were reviewed by both Choice and Library Journal. Undoubtedly some of the other books on

TABLE 2. Books COVERED IN LiBRARY REVIEWING Journals

\begin{tabular}{|c|c|c|c|}
\hline Philosophy Journal & $\begin{array}{c}\text { No. of Titles } \\
1964\end{array}$ & $\begin{array}{l}\text { Library } \\
\text { Journal }\end{array}$ & Choice \\
\hline $\begin{array}{l}\text { Aesthetics } \\
\text { History of }\end{array}$ & 15 & $\cdots$ & $\cdots$ \\
\hline $\begin{array}{l}\text { Philosophy } \\
\text { Journal of }\end{array}$ & 46 & 1 & $\ldots$ \\
\hline $\begin{array}{l}\text { Philosophy } \\
\text { Mind }\end{array}$ & 31 & 1 & 1 \\
\hline $\begin{array}{l}\text { Mind } \\
\text { Philosophical } \\
\text { Books }\end{array}$ & 28 & 1 & $\ldots$ \\
\hline $\begin{array}{l}\text { Books } \\
\text { Philosophical } \\
\text { Review }\end{array}$ & $\begin{array}{l}63 \\
35\end{array}$ & 7 & 7 \\
\hline $\begin{array}{c}\text { Philosophical } \\
\text { Quarterly } \\
\text { Philosophy }\end{array}$ & $\begin{array}{l}48 \\
17\end{array}$ & $\begin{array}{l}2 \\
2\end{array}$ & … \\
\hline $\begin{array}{l}\text { Phil. and Phen. } \\
\text { Research } \\
\text { Phil. East and }\end{array}$ & 44 & 1 & $\ldots$ \\
\hline $\begin{array}{l}\text { West } \\
\text { Philosophy of } \\
\text { Science }\end{array}$ & $\begin{array}{r}21 \\
8\end{array}$ & 2 & \\
\hline $\begin{array}{l}\text { Review of } \\
\text { Metaphysics } \\
\text { Symbolic Logic }\end{array}$ & $\begin{array}{r}123 \\
14\end{array}$ & 7 & 14 \\
\hline & & & \\
\hline
\end{tabular}

philosophy would have been covered in earlier issues of Choice, had it been published in 1963, but even if one were to double the number and assume a total of thirty-two books covered in the twoyear period, Choice would be but a first step toward finding the 493 philosophy books reviewed by the journals in this field in 1964.

The librarian must decide how broad a coverage of reviews he will read in order to do his selection in any one field. Perhaps staff size will not permit the careful reading of all thirteen journals cited. Perhaps it will be decided that aesthetics is not really in the field of philosophy and can be excluded. Perhaps the size or interest of the student body would warrant the exclusion of Philosophy East and West. Perhaps the small number of books covered in Philosophy (a total of seventeen, nine of which had been picked up by other journals) would mean that one could be put aside. The same could perhaps be said for Symbolic Logic, although this is a valuable reference journal for the profession; it is the only one to review articles, and in terms of bibliography within the subject it is invaluable. A journal like Mind, although many of its books are covered by others, is nevertheless one of the leading journals in the field and to deprive oneself of its point of view and undoubted authority is something that ought not to be done lightly.

Philosophy is a complex subject, and to cover it adequately in a college or university library requires a large number of specialized journals, a large number of titles to be considered, and a staff able to distinguish a "good" philosophy book from a "bad" one. Surely with a "good" philosophy department much of the decision-making will be done by teaching faculty, but the librarian must face the fact that it will take a great amount of care and reading and work to build up a first-rate, or even a secondrate collection in this field. 